\title{
Sjogren's SS-B Antibody Measurement
}

National Cancer Institute

\section{Source}

National Cancer Institute. Sjogren's SS-B Antibody Measurement. NCI Thesaurus. Code C92237.

The determination of the amount of Sjogren's SS-B antibody present in a sample. 